\title{
Assessment of students' reading culture in a Nigerian university: Waxing or waning?
}

\author{
Bosede Sotiloye \\ Associate Professor \\ Department of Communication and General Studies \\ Federal University of Agriculture, Abeokuta, Nigeria \\ E-mail: sotiloyebs@funaab.edu.ng; bssotiloye@yahoo.com
}

\author{
Helen Bodunde \\ Professor \\ Department of Communication and General Studies \\ Federal University of Agriculture, Abeokuta, Nigeria \\ E-mail: bodundeha@funaab.edu.ng; adukehelen@gmail.com
}

Submitted: September 2, 2017 / Accepted: March 3, 2018 / Published: December 3, 2018

\begin{abstract}
This study assessed the trend of the reading culture of the students of the Federal University of Agriculture, Abeokuta (FUNAAB), Nigeria. The respondents' level of study, preferred language skill, frequency and duration of reading, and types of materials read were examined. Using a descriptive survey design, data was collected from 509 students in the first and last years of study across eight colleges by means of a questionnaire. The findings revealed that the most preferred language activity was reading with a high percentage engaging in it daily. Most students only read to pass examinations as they hardly engaged in any reading outside school books. A relationship between the students' level and their reading culture was established. Amongst other recommendations, students were encouraged to read magazines, novels, and other recreational materials in order to improve their reading habits.
\end{abstract}

Keywords: literacy, reading culture, reading frequency, reading materials, recreational reading 


\section{Introduction}

Reading, one of the most fundamental building blocks of learning, is a process that requires the use of complex thought processes to interpret printed symbols as meaningful units, and to comprehend them as a thought unit in order to understand a printed message (Aina, Ogungbemi, Adigun, \& Ogundipe, 2011, p. 1; Onuoha, Unegbu, \& Umahi, 2013, p. 2). In other words, reading is a process of decoding symbols in order to derive or construct meaning. Reading is, therefore, vital for everyday activities of being better informed, sharpening and shaping the mind, rational and objective reasoning leading to greatness in life. Reading is also said to be an encapsulating process which is integrative in nature, and which affects the reader's perceptual, cognitive, and affective domains (Oriogu 2013, p. 61). Simply put, reading is not just for school, it is for life! It is affirmed that humans are capable of transmitting knowledge to succeeding generations through reading. This confirms the assertion that success in school or any life endeavor is dependent on a good foundation in reading competence (Oriogu, 2013, p. 61).

Reading has been said to be the only form of entertainment that is also an essential life skill. Gentile (1976, p. 378) argues that "reading allows an individual the opportunity to grow and develop insights into life and the world at large. Thus, he is able to make effective decisions that lead to personal health and happiness". Reading is one of the most rewarding pursuits in life and an art that is central to human development. Therefore, developing a reading culture is pertinent to success in life.

Reading culture is the process of building up a positive reading attitude. This is when reading becomes a part of the individual's life and not only certain aspects, such as school or work. Phillip (2005, p. 1) affirms that reading is not just for the acquisition of literacy, but also for the cultivation of the habit of reading when he stated: 
Giving someone literacy skills is rather like teaching a person to drive and then giving them only a few drops of petrol to practise with - the machine is perfect and the driving skill has been acquired but it is not yet an automatic skill because there has not been enough practice. Once the fuel runs out, the driving skill becomes useless and begins to deteriorate. With a harnessed reading culture, on the other hand, the person is provided with a continuous supply of easily processed fuel so that the new driver can go places, can get to enjoy driving and can eventually realize the limitless possibilities it opens up.

Reading culture is best developed in the formative years of the child. This is why reading should be a major part of the school curriculum and also, an instrument of thoroughly understanding the subject-matter of any school subject. Reading is one of the fundamental skills which students are expected to acquire through the process of schooling without which there would possibly be no other means of achieving academic success (Oyewole, 2017, p. 92).

\section{Reading culture in different climes}

Societies and nations, consciously or unconsciously, view and value the concept of reading differently. A reading nation is said to be a growing nation as the way of life of a nation is influenced by the percentage of its literate citizens - the more and better literate, the better developed. According to Palani (2012, p. 91), consciously creating a good reading habit is an essential and important aspect of creating a literate and developed society. For example, Cuba, despite decades of diplomatic conflicts with the United States of America, is said to have the highest rate (99.8\%) of literacy in the world and this accounts for its vibrant economy. Britain, which also places a high premium on reading, has about $99 \%$ of her citizens being able to read and write (CIA World Factbook, 2015, p. 139). A 2015 Nielsen Bookscan report indicates that out of the $67 \%$ who bought books in the United States of America in 2014, 59\% 
actually read a book per day, whereas, a survey carried out in 2015 by Booktrust shows $76 \%$ of the 1500 adults quizzed on reading habits in the UK to have enjoyed the act. The reading habit in the United States of America is also high as it is reported that in 2013, some $76 \%$ of American adults aged 18 and above stated that they read at least one book in the past year (Zickuhr \& Raine, 2014, p. $1)$.

However, the reading culture in developing societies such as Nigeria with a literacy level of $59.6 \%$, Ethiopia $49.1 \%$. Benin $38.4 \%$ (CIA World Factbook, 2015, p. 139) is very low. In Nigeria, for example, reading is associated with passing examinations and is seen as a means of accomplishing academic success. This mindset reflects in students' lack of inspiration to read in their leisure time and outside their disciplines since they associate reading with textbooks and attending school. It is revealed that $40 \%$ of adult Nigerians hardly engage in reading non-fiction books (Ilori \& Abdullahi, 2006, p. 145). The average Nigerian reads less than one book per year, and only one percent of successful men and women in Nigeria read one non-fiction book per month. It further showed that 30 million Nigerians have graduated from high school with poor reading skills. It was reported that in 2006, South African Grade 4 and Grade 5 learners came last in a study of 40 countries that took part in the Progress in International Reading Literacy Study (PIRLS) (Mullins, Martin, Kennedy \& Foy, 2007, p. 37).

Another project reveals that South African Grade 6 learners were the second-worst readers from a group of 15 countries in Southern and Eastern Africa (Kruger, 2011, p. 1). Janse van Vuuren (2011, p. 9) contends that the South African population cannot be described as a book reading nation. The results of the studies in the developing countries corroborate an old saying that "if you want to hide something from a Black person, put it in a book" meaning that Black people do not like to read. This behaviour may be attributable to the fact that traditionally, Black people generally relied on oral communication to document history and to communicate.

The efforts of various governmental and non-governmental 
agencies, and the media in spearheading the promotion of reading culture in the African society are, however, commendable. Notable amongst these are the Pan African Reading Society, and the Writers and Readers Interactive and Total Empowerment Scheme for Africa (WRITES Africa). The former organizes conferences and literacy events on the African continent, providing platforms for literacy professionals and researchers to interface with policy makers in government and the donor community. It is reported that positive developments have been experienced in the eight countries (South Africa (1999); Nigeria (2001); Uganda (2003); Swaziland (2005); Ghana (2007); Tanzania (2009); Botswana (2011); and Kenya (2013) where the conference has been held (RASA, 2015). The mission of WRITES Africa is to "completely change the mentality of African youths towards reading and totally inculcate the reading and writing spirits into the innermost recesses of their hearts". It was established to promote the reading culture in Nigeria in particular and Africa as a whole. The project, which includes a reality TV show, is designed to expose the youth to the process of nation-building through self-discovering reading.

\section{Reading culture and school performance}

Reading, a major aspect of literacy, is essential for the acquisition and transfer of knowledge, and academic achievement. A reading culture of deliberate and well-planned study habit is, therefore, very important in attaining success in school, and life in general. In other words, reading and success are dependent on each other. However, the prevailing conditions in many societies is that reading is fast losing popularity as the television, internet, and various forms of new technologies have reduced the reading culture so much so that it has negatively affected school performance. The decline in reading appears to be a direct consequence of technological advancements and this has brought about significant changes in family, social, and economic conditions (OwusuAcheaw \& Larson, 2014, p. 4). The society, including students of school age, no more reads books for pleasure, but would rather get entertained listening to music, watching home videos, or chatting 
on social media. In Nigeria, the rate of failure recorded by students in qualifying examinations, such as the West African Examinations Council (WAEC), National Examinations Council (NECO) and the Joint Admission Matriculation Board (JAMB) is a clear indication of the effect of lack of reading culture on school performance. Adetulu (2016) reveals that the dearth of reading culture and the absence of equipped libraries have been identified as the two causative agents in the $80 \%$ failure rate recorded among Nigerian youth. Research on the study habits of undergraduates also revealed that students have a negative attitude towards reading and this often affects their performance in class and examinations (Akabuike \& Asika, 2012; Oriogu, Subair, Oriogu-Ogbuiyi, \& Ogbuiyi, 2017). It is against the backdrop of dwindling reading culture that the current research was embarked upon to find out, amongst others, if the class level of students in tertiary institutions has an effect on their reading habit. Is their reading culture waxing or waning?

\section{Theoretical framework}

The current study is anchored on the social behaviour theory of symbolic interactionism as propounded by Mead (1934), developed by Blumer (1969/1986), and further expounded by Milliken and Schreiber (2012). The theory presents language, meaning, and thoughts as inextricably linked concepts of communication in the process of socialization by interaction (Mead, 1934, pp. 89-90 as cited in Cronk 2001). As Milliken \& Schreiber (2012, pp. 688-689) put it, the "meaning of objects (words) ... arise(s) from, and (is) modified by, the social interaction through which people engage with them". Blumer (1969) highlights human interaction with things, others and the society based on meanings ascribed to them and the interpretation given when dealing with things in specific circumstances as the premises on which symbolic interactionism is based. Reading, an art which involves the decoding of symbols in the derivation and interpretation of meaning, can influence and guide students' social behaviour and interaction with others in the society. Reading habits can be linked to academic performance and even job performance later in life. 


\section{Statement of the problem}

A good reading habit has been established as essential for academic success. It stands to reason then that the more students read, the better their academic performance; and the higher they move up the academic ladder, the more they ought to engage in reading. However, it seems the social media with its features of dynamism, visual appeal, and brevity is making students engage less in reading. This effect of loss of interest in reading is greater on science students than on their counterparts in the arts who tend to have a greater motivation for reading. With the intent of assessing if class level affects reading habits, this research examines first and final year students of the Federal University of Agriculture, Abeokuta (FUNAAB) in South West Nigeria. Do they read more, or less, as they progress in school?

\section{Objectives of the study}

The study set out to:

i. ascertain the level of reading culture among Nigerian undergraduates

ii. assess the frequency of the respondents' reading

iii. determine what constitute tertiary institution students' reading habits

iv. assess the relationship between students' level in the University and their reading culture

\section{Research questions}

i. What is the level of reading culture among undergraduates?

ii. What is the frequency of the respondents' reading?

iii. What are the reading habits of tertiary institution students?

iv. Is there any relationship between students' level in the University and their reading culture? 


\section{Methodology}

The study was carried out at the Federal University of Agriculture, Abeokuta (FUNAAB) in South West Nigeria. The university, established in 1988, is a non-conventional institution offering mostly agriculture-based courses, some natural sciences, and recently social and management sciences courses. The respondents were randomly selected first and final year students across eight of the University's colleges. The reactions and responses of 509 first and final year students to the culture of reading were assessed. The study adopted a descriptive survey design with the research instrument for data collection being a questionnaire which was used to obtain, amongst other parameters, data on respondents' level of study, reading habits such as the frequency and duration of reading, and the types of materials read. Results were analysed using simple percentages.

\section{Results}

\section{Demographic characteristics of respondents}

Five hundred and nine (509) students served as respondents in this study. A consideration of their level of study reveals that two hundred and ninety seven (297) students, constituting 58.3\% of the respondents, were in year one while two hundred and twelve (212) that is, $41.7 \%$ of the respondents were in the final year.

Table 1: Respondents' level of study

\begin{tabular}{lll} 
Level & Frequency & Percentages \\
Year one & 297 & 58.3 \\
Final year & 212 & 41.7 \\
Total & $\mathbf{5 0 9}$ & $\mathbf{1 0 0}$ \\
\hline
\end{tabular}

Source: Field Survey 2016

\section{College distribution of respondents}

Table 2 shows that majority of the respondents $(47.7 \%)$ were in the Agriculture Programme which is run by three Colleges: College of Agricultural Management and Rural Development 
(COLAMRUD), College of Animal Science and Livestock Production (COLANIM), and College of Plant Science and Crop Production (COLPLANT); College of Natural Sciences (COLNAS) had (23.8 \%); College of Food Science (COLFHEC) had (11.2\%); College of Environmental Resources Management (COLERM) (10.8\%); College of Engineering (COLENG) was (3.9\%); and College of Veterinary Medicine (COLVET) (2.6\%). (The last two Colleges normally admit very few students hence the low sample).

Table 2: College distribution of respondents

College

COLAMRUD

COLANIM

COLPLANT

COLNAS

COLFHEC

COLERM

COLENG

COLVET

Total
Frequency

75

89

79

121

57

55

20

13

509

\section{Percentage}

14.7

17.5

15.5

23.8

11.2

10.8

3.9

2.6

100

Source: Field Survey 2016

\section{Reading culture of respondents}

Despite the fact that students' reading culture is generally said to be low, most respondents $(59.3 \%)$ submitted to having preferred reading to writing $(16.7 \%)$, listening $(13.7 \%)$, and speaking $(7 \%)$. Table 3 indicates that more students would read than engage in other language skills. 
Sotiloye, B. and Bodunde, H./Assessment of students 'reading culture in a Nigerian university

Table 3: Response of students on language activities

\begin{tabular}{|l|l|l|}
\hline $\begin{array}{l}\text { Which of these skills do } \\
\text { you prefer doing? }\end{array}$ & Frequency & Percentage \\
\hline Reading & 302 & 59.3 \\
Writing & 85 & 16.7 \\
Listening & 70 & 13.7 \\
Speaking & 35 & 7 \\
Undecided & 17 & 3.3 \\
\hline Total & $\mathbf{5 0 9}$ & $\mathbf{1 0 0}$ \\
\hline
\end{tabular}

Source: Field Survey 2016

The frequency of students' reading was also considered. Table 4 reveals that daily reading was the most common among the students, followed by weekly reading. Fewer percentages of the students stated that they read monthly (4\%) and occasionally (12 $\%)$.

Table 4: Reading frequency

\begin{tabular}{|l|l|l|}
\hline How often do you read? & Frequency & Percentage \\
\hline Daily & 330 & 65 \\
Weekly & 95 & 19 \\
Monthly & 22 & 04 \\
Occasionally & 62 & 12 \\
\hline Total & $\mathbf{5 0 9}$ & $\mathbf{1 0 0}$ \\
\hline
\end{tabular}

Source: Field Survey 2016

On assessing how long the students read continuously, it was established that the duration of reading at a time among the students differed. 
Table 5: Reading duration

\begin{tabular}{|l|l|l|}
\hline How long do you read at a stretch? & Frequency & Percentage \\
\hline 0 -30 min. & 30 & 5.9 \\
$31-60 \mathrm{~min}$. & 70 & 13.8 \\
$61-90 \mathrm{~min}$. & 140 & 27.5 \\
$91-120 \mathrm{~min}$. & 110 & 21.6 \\
120 and above & 159 & 31.2 \\
Total & $\mathbf{5 0 9}$ & $\mathbf{1 0 0}$ \\
\hline
\end{tabular}

Source: Field Survey 2016

As shown in Table 5, many of the students (31.2\%) read for over two hours at a stretch while only $5.9 \%$ of the students read for about 30 minutes at a time. The percentage of those who read between one and a half and two hours at a stretch was almost $50 \%$. This shows that the respondents have quality reading time.

\section{Reading materials and environments}

The study sought to investigate the reading habits of students with particular reference to what they read, and where they read. Table 6 shows that prescribed school books constitute the most read materials as indicated by $62 \%$ of the respondents. This declaration is corroborated by the high percentage $(66.4 \%)$ of those who also agreed to have read texts relevant to their course of study. Some $15.7 \%$ claim to read religious and motivational books, $14.2 \%$ and $5.5 \%$ read novels and comics respectively. The result confirms the 'reading to pass' mindset of most students and also reveals that students hardly read for pleasure. 
Table 6: Responses of students on reading habit

What kind of materials do you Frequency Percentage read?

Prescribed school books

316

62

Religious/motivational

80

15.7

Novels

72

14.2

Comics

$28 \quad 5.5$

Others

13

2.6

Total

509

100

I usually read texts relevant to my course

Agree

338

66.4

Disagree

124

24.6

Undecided

46

9

Total

509

100

Where do you read?

Anywhere

278

54.6

Library

196

38.5

Classroom

23

4.5

Noisy environment

12

2.4

Total

509

100

Do you take pleasure in reading?

Very well

245

48

Moderately well

185

36

Fairly

79

16

Total

509

100

Source: Field Survey 2016

The reading environment is believed to have effect on reading habit. It would seem natural that a serene, as opposed to 
a noisy, study environment would lead to better understanding. In this study, $54.6 \%$ of respondents submitted to reading anywhere. Only $38.5 \%$ read in the library while $4.5 \%$ and $2.4 \%$ read in the classroom and even noisy environments, respectively. The attitude of reading anywhere would probably reduce students' level of comprehension of read texts. The level of pleasure derived from reading among the students varied. Forty-eight percent (48\%) of the respondents claim to derive high pleasure from reading, $36 \%$ got moderate pleasure while only $16 \%$ of the students declared to have fairly enjoyed reading. Though a higher percentage indicated they enjoyed reading, it may be assumed that their reading is precipitated by the need to do well in their academic work.

Table 7 is a juxtaposition of the reading habits of the respondents according to levels - first and final years of study. Reading, as an activity, was preferred to other language skills irrespective of the student's level. However, more first year respondents $(64 \%)$, as against $52.8 \%$ of the final year, submitted to have preferred reading. With respect to frequency of reading, more final year students seemed to be lackadaisical having $15 \%$ and $32 \%$ reading on a monthly or occasional basis respectively. The first year students, however, recorded $7 \%$ and $30 \%$ respectively. Remarkably, more first year respondents (71\%) read on a daily basis. 
Sotiloye, B. and Bodunde, H./Assessment of students' reading culture in a Nigerian university

Table 7: Patterns in the reading culture of first and final year students

\begin{tabular}{|c|c|c|c|c|}
\hline Question & $\begin{array}{l}\text { First } \\
\text { Year } \\
(n=297)\end{array}$ & Percentage & $\begin{array}{l}\text { Final } \\
\text { Year } \\
(n=212)\end{array}$ & Percentage \\
\hline \multicolumn{5}{|l|}{$\begin{array}{l}\text { Which do you prefer } \\
\text { doing? }\end{array}$} \\
\hline Listening & 30 & 10 & 40 & 18.9 \\
\hline Speaking & 20 & 6.8 & 15 & 7.1 \\
\hline Reading & 190 & 64 & 112 & 52.8 \\
\hline Writing & 50 & 16.8 & 35 & 16.5 \\
\hline Undecided & 07 & 2.4 & 10 & 4.7 \\
\hline \multicolumn{5}{|l|}{ How often do you read? } \\
\hline Daily & 210 & 71 & 120 & 56.6 \\
\hline Weekly & 50 & 17 & 45 & 21.2 \\
\hline Monthly & 07 & 2 & 15 & 7.1 \\
\hline Occasionally & 30 & 10 & 32 & 15.1 \\
\hline \multicolumn{5}{|l|}{$\begin{array}{l}\text { For how long do you read } \\
\text { at a stretch? }\end{array}$} \\
\hline $0-30 \mathrm{~min}$ & 10 & 3.4 & 20 & 9.4 \\
\hline $31-60 \mathrm{~min}$ & 35 & 12 & 35 & 16.5 \\
\hline $61-90 \min$ & 80 & 27 & 60 & 28.3 \\
\hline $91-120 \min$ & 70 & 23.6 & 40 & 18.9 \\
\hline 120 and above & 102 & 34 & 57 & 26.9 \\
\hline $\begin{array}{l}\text { How well do you take } \\
\text { pleasure in reading? }\end{array}$ & & & & \\
\hline Very well & 150 & 50.5 & 95 & 44.8 \\
\hline Moderately well & 100 & 33.7 & 85 & 40.1 \\
\hline Fairly well & 47 & 15.8 & 32 & 15.1 \\
\hline
\end{tabular}

Source: Field Survey 2016

The students' length of study time was significantly influenced by their level as most of the students in year one (34 
\%) read for more than 2 hours and above while most students in the final year $(28.3 \%)$ barely read for more than an hour. It was also established that more final year students $(9.4 \%)$ as opposed to $3.4 \%$ of year one students read for just 30 minutes. Both sets, however, declared to have derived at least some moderate pleasure from reading with $84.2 \%$ for the first year and $84.9 \%$ for the final year students.

The findings on the relationship between the students' level of study and their reading culture are graphically represented in Figure 1 below:

\section{Relationship between student's level and reading culture}

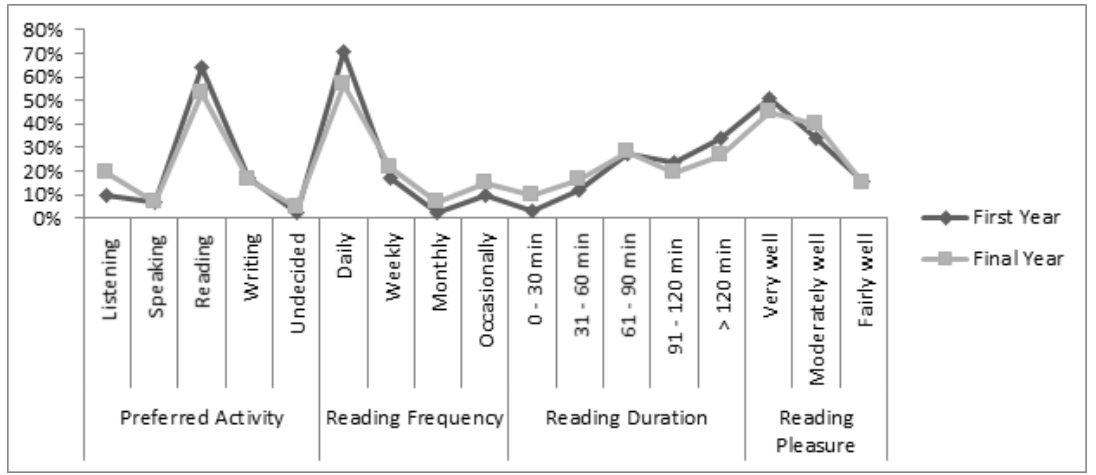

Figure 1: Relationship between student's level and reading culture

\section{Discussion}

According to the findings, $59.3 \%$ of the undergraduates sampled prefer reading to other language activities. The level of reading is a bit above average, which is considered good compared to the general notion that undergraduates do not read. This result, however, becomes worrisome when we consider the fact that good readers are presumed to be good writers. Available literature shows that the writing skills of Nigerian undergraduates are well below average as revealed in studies by Aborisade (2003), and Oguntuase (2003) at the Federal University of Technology Akure; Adelabu and Fadimu (2004) at the Federal University of Technology, Makurdi. 
Onukaogu (2005) and Bodunde and Sotiloye (2013) also recorded poor writing performance of students in Obafemi Awolowo University, Ile-Ife, and the Federal University of Agriculture, Abeokuta, respectively.

The increase in reading interest might, however, be attributable to the fact that 100 level students are generally eager to do needful assignments and thus may be forced to read. Their exposure to GNS 101 (Use of English) which requires that they read literary works may also be a plausible reason. Generally, it is expected that undergraduates' reading materials include recommended school books as well as novels, magazines, comics, religious/motivational books, and some other materials as these are expected to prepare them for a total life. However, this research shows that over half of the respondents $(62 \%)$ read only school books and $64 \%$ read materials related to school work which gives the impression that respondents did not engage in extracurricular reading. They only read to pass examinations! This suggests that in the absence of school books, students will probably not read to gain knowledge or broaden and educate their minds.

The results of the study also corroborate previous findings that the culture of reading in Africa, particularly in Nigeria, is linked only with schooling (Louise, 2008). The value system encourages reading whenever one must write examinations or school assignments. This may invariably affect their work performance after graduation, especially if their job description demands reading.

The study has confirmed the mindset surrounding the Nigerian formal education revolving around paper qualification which was further emphasized by the percentage of students (64\%) who agreed to have read only texts relevant to their field of study. In other words, students tend not to read extensively outside their fields for them to be exposed to other disciplines. Owusu-Acheaw \& Larson (2014, p. 19) working on Ghanaian students' reading habits discovered that $87 \%$ of the students read lecture notes or their textbooks whenever they visited the library while only $3 \%$ read novels, and $10 \%$ other materials. 
The low reading habit of non-school books can be attributed to the access to home videos, cartoons and comic materials made affordable by the emergence of ubiquitous technologies which give students the opportunity to watch these on mobile phones and other such devices. The lack of interest in reading for pleasure has, however, gained the attention of some associations; governmental as well as non-governmental agencies that are making concerted efforts to promote and improve reading proficiency in various African countries. One such agency is the Open Library Project, an initiative to nurture and maintain a reading for pleasure culture in Kenya. This actually had a positive impact on the participants, and the society at large, with Kenya's literacy level rising up to $78 \%$ in 2015 (CIA World FactBook, 2015). In 2011, the African Library Project (ALP) a non-governmental agency in Swaziland was also reported to have started establishing and operating Fundza (Sisiwati word for "to learn" or "to read") libraries to which students were exposed in order to improve their reading habits (ALP Newsletter, 2017). Furthermore, Associations such as, the Reading Association of South Africa, and Reading Association of Nigeria are trying to improve the literacy level in their respective communities.

There seems to be a relationship between the students' level and their reading culture as Table 7 reveals that $64 \%$ of year one undergraduates engaged in reading as against $52.5 \%$ of the final year students. It could be postulated that the final year students did not read as much as the first year students because they depend on the existing grade points they had made during their earlier years in school, whereas the year one students read to build up their Cumulative Grade Points so as to be able to graduate with high grades. It could also be attributable to the fact that first year students have more courses to offer, and have the zeal to read more as is expected of fresh university students. The difference in the length of study time of the first and final year students is of great concern. The negative trend may culminate in students' cessation of reading after graduation. It has been observed that though a combination of the study time and other factors may explain students' academic 
performance, students who are very successful in their desired career have longer study time (Kunal, 2008). A thirty-minute study time would probably not lead to academic excellence.

Based on the premise of symbolic interactionism which interprets human behaviour through people's interaction with things, others, and the society, it is presumable that students who engage in the art of reading have the tendency to score high grades while low grades may be interpreted as having lesser interaction with reading materials.

\section{Conclusion}

It can be concluded from the findings that, of the four language skills, reading was the most preferred by the students while speaking was the least on the list. Most of the students engaged in reading daily and read for two and a half hours at a stretch. However, the majority read only school prescribed books while very few read novels and comics. This is an indication that they did not read for pleasure meaning and did not engage in extensive reading. A comparison of the reading habit of the first and final year students revealed a waning trend in that the former engaged in the act of reading more than the final year students and read for a longer period of time. This may be explained by the fact that the first year students have to take many basic and foundation courses which demand more reading.

\section{Recommendations}

Based on the findings of the study and the discussions, it is recommended that a vibrant reading culture be created in students, right from the cradle, through interesting educative indoor games that demand the use of the reading skill. Reading habits can be developed using several educational games, such as scrabble, monopoly, and chess. Students at the primary and secondary school levels should be encouraged to enrol for vocabulary developing competitions such as the scrabble game, debates, or spelling competitions. Since majority of the undergraduates limit themselves to prescribed books, it is recommended that courses 
and programmes be expanded to include more liberal arts books or even the introduction of reading courses. The South African One-Book-One-Library project, where everyone in the university community was made to read one book at the same time, could be adopted or adapted in Nigeria. School libraries should be wellequipped and effort be made to attract students of different ages to read by introducing various incentives such as giving out tickets to eat at a restaurant, ticket to a book launch, or even scholarships to those who excel in reading competitions.

Furthermore, communities should build up or update their libraries and form Readers Associations through which children as well as adults can develop or improve their reading skill. Students should be encouraged to read magazines, novels, and other materials instead of reading textbooks all the time. It has been established that students, who read magazines at intervals learn to relax, cool their brain, and avoid mental fatigue. It is pertinent to encourage students to set an effective study time-table and stick to it. This can be achieved if students are taught effective time management to accommodate extensive reading. Everyone should be encouraged to read outside school or work, and read for pleasure as that is an avenue to make great minds which would culminate in the construction of a great nation.

Language courses, specifically on reading, could be made compulsory for all students as is obtainable in some institutions like the Daystar University in Kenya where all students, irrespective of their major courses, are made to take Advanced Reading and Advanced Writing. The same university has also established a Writing and Speech Center where students, through peer-tutoring, learn to improve their writing and speech abilities. Institutions can extend this to reading whereby students can practice reading in a fun-filled and relaxed atmosphere outside the classroom setting. It is also appropriate that the big distraction of the new technology give way, be curtailed, or modified so that students' reading habits can improve. Instead of being glued to the mobile phone, television, or internet and engaged in activities that have limited educational advantage, students can actually make use of e-book facilities of the 
Sotiloye, B. and Bodunde, H./Assessment of students' reading culture in a Nigerian university new technology. Finally, it is recommended that further research be undertaken to shed more light on the reading habits of students in more tertiary institutions to cover more geo-political domains of the country and the continent. 


\section{References}

Aborisade, P. (2003). An analysis of some discourse features in biological science research reports: Implications for EST course. ELTT: A Journal for Teachers of English and Communication Skills, 2 (2), 7-13. Adelabu, B., \& Fadimu, T. (2004). An examination of written English errors among first year undergraduates in a Nigerian university. ELTT: A Journal for Teachers of English and Communication Skills, 3 (1), 5461.

Adesulu, D. (2016, March 24). 80\% fail NECO, WAEC, JAMB over dearth of reading culture Vanguard Newspaper Retrieved from http://www. vanguardngr.com

African Library Project Newsletter. (2017). Retrieved from https://www. africanlibraryproject.org

Aina, A., Ogungbemi, J., Adigun, J., \& Ogundipe, T. (2011) Poor reading habits among Nigerians: The role of libraries. Library Philosophy and Practice (e-journal) 529.

Akabuike, I., \& Asika, I. (2012). Reading habits of undergraduates and their academic performances: Issues and perspectives. African Research Review, 6 (2), 246 - 257.

Blumer, H. (1986). Symbolic interactionism: Perspective and method. Berkeley, CA: University of California Press. (Original work published 1969). Retrieved from https://www.scribd.com/doc/259098184/2-HerbertBlumer-Symbolic-Interactionism-Perspective-and-Method-1986-Libre

Bodunde, H., \& Sotiloye, B. (2013). A critique of undergraduate students' writing skill in an ESL setting: Samples from the Federal University of Agriculture, Abeokuta, Nigeria. World Journal of English Language, 3 (2), 10-21.

Booktrust Reading Habit Survey. (2013). Retrieved from https://www. booktrust.org.uk

CIA Worldfactbook. (2015). Retrieved from https://www.cia.gov/library/ publications/the-world-factbook/fields/2013\#139

Cronk, G. (2001). The evolution of the psychical element: George Herbert Mead at the University of Chicago. Internet encyclopedia of philosophy. Retrieved from https://www.iep.utm.edu/mead/

Gentile, L.M. (1976). Why is reading so special? Journal of Reading, 19 (5), 378-380.

Ilori, M., \& Abdullahi, M. (2016). Promoting reading habit among secondary school students in Lagos state: The role of library \& ICT Asian Online Journals, 4 (5), 145-152.

Janse van Vuuren, A. (2011). Communal reading as a way to foster a reading culture: The one-book-one-library project at the University of Johannesburg

Kruger, C. (2011, April 03). SA pupils fail to make the grade. News24, Retrieved from http://m.news24.com/news24/SouthAfrica 
Sotiloye, B. and Bodunde, H./Assessment of students 'reading culture in a Nigerian university

Kunal, D. S. (2008). Cultivating competence, self-efficacy and intrinsic interest through proximal self-motivation. Journal of Personality and Social Psychology, 4 (3), 586-598.

Louise, P. (2008). Different kinds of reading culture. China Daily PDF Edition.

Milliken, P. J., \& Schreiber, R. (2012). Examining the nexus between grounded theory and symbolic interactionism. International Journal of Qualitative Methods, 11 (5), 686 -696. Retrieved from https:// journals. library.ualberta.ca

Mullins, I. V. S., Martin, M. O., Kennedy, A. M., \& Foy, P. (2007). PIRLS 2006 international report: IEA's progress in international reading literacy study in primary schools in 40 countries. Chestnut Hill, MA: TIMSS \& PIRLS international study centre, Lynch school of education.

Nielsen Bookscan. (2015). Know what's next in the book industry Retrieved from www.nielsen.com/us/en/insights/.../2015-us-book-industry-yearend-review.html

Oguntuase, F. (2003). Assessing written communicative competence and productive functions of 100 level engineering students. ELTT: A Journal for Teachers of English and Communication Skills, 2 (2), $32-38$

Onukaogu, C. (2005). Literacy for empowerment: Making things happen in the use of English program. Keynote address presented at the 3rd Annual Conference of National Association of Teachers and Researchers of English as a Second Language (NATRESL) 5th-7th Oct., 2005.

Onuoha, U., Unegbu, E., \& Umahi, F. (2013). Reading habits and library use among students of information resources management, Babcock University, Nigeria. Journal of Education and Practice, 4 (20), 98-103

Oriogu, D. (2015). Catch them young: Developing and improving of school libraries and reading habit of secondary school students in Nigeria. Journal of Education and e-Learning Research, 2 (4), 60 -63

Oriogu, C., Subair, R., Oriogu-Ogbuiyi, D., \& Ogbuiyi, S. (2017). Effects of reading habits on the academic performance of students: A case study of students of Afe Babalola University, Ado-Ekiti, Ekiti State American Journal of Library and Information Science, 1 (1), 27- 33.

Oyewole, O. (2017). Impact of poor reading culture among selected secondary school students in Owo local government area of Ondo state, Nigeria. Developing Country Studies 7 (10), 88 - 101

Owusu-Acheaw, M ., \& Larson, A.G. (2014). Reading habits among students and its effect on academic performance: A study of students of Koforidua Polytechnic. Library Philosophy and Practice (e-journal), Paper 1130. Retrieved from http://digitalcommons.unl. edu/libphilprac/1130

Palani, K. K. (2012). Promising reading habits and creating literate society. International Reference Research Journal III, 2 (1), 91. 
Phillip, A. (2005). The reading habit - A missing link between literacy and libraries. Retrieved from http://www.pngbuai.com/000general/ libraries/literacy-services/READRAB.pdf

Readers Association of South Africa. (2015). Imagination and literacy: Theory and practice Conference, Cape Town 2-5 September, 2015. Retrieved from www.rasa2015.co.za

Zickuhr, K., \& Rainie, L. (2014). A snapshot of reading in America in 2013 who is reading- and how: A demographic portrait. Retrieved from www.pewinternet.org

https://www.bookaid.org/2017/07/12/salupdate

https://www.writesafrica.net/about.php

http://www.peoplesdailyng.com/evaluating-nigerias-dwindling-reading-culture

http://www.daystar.ac.ke/SCLPA-programs.html 